\title{
Jumlah Sel Leydig dan Mikroanatomi Testis Tikus Putih (Rattus norvegicus) Setelah Pemberian Teh Kombucha Konsentrasi 50\% Waktu Fermentasi 6, 9 dan 12 Hari
}

\section{The Number of Leydig Cells and Testicular Microanatomy Structure of Rattus Norvegicus After Consumption Fermented Kombucha Tea 6, 9 And 12 Days on 50\% Level}

\author{
Sri Isdadiyanto*, Silvana Tana \\ Departemen Biologi Fakultas Sains dan Matematika Universitas Diponegoro \\ *Email : isdadiyanto@yahoo.com
}

Diterima 13 Mei 2019 / Disetujui 20 Februari 2020

\begin{abstract}
ABSTRAK
Tujuan penelitian ini untuk mengkaji potensi teh Kombucha kadar 50\% dengan variasi waktu fermentasi dalam mempengaruhi jumlah sel leydig dan struktur mikroanatomi testis tikus putih (Rattus norvegicus). Penelitian ini menggunakan Tikus putih jantan sebanyak 16 ekor umur 2 bulan, dengan perlakuan Teh kombucha yang difermentasi selama 6,9 dan 12 hari pada suhu $25^{\circ} \mathrm{C}$ per oral. Penelitian ini menggunakan Rancangan Acak Lengkap dengan 4 perlakuan (selama 28 hari) dan 4 ulangan, yaitu : P0 = kontrol, tanpa tambahan teh kombucha, $\mathrm{P} 1=$ air minum $+1,8 \mathrm{ml}$ teh kombucha pagi dan sore fermentasi 6 hari, $\mathrm{P} 2=$ air minum $+1,8 \mathrm{ml}$ teh kombucha pagi dan sore fermentasi 9 hari, $\mathrm{P} 3=$ air minum $+1,8 \mathrm{ml}$ teh kombucha pagi dan sore fermentasi 12 hari. Variabel yang diukur adalah diameter tubulus seminiferus dan jumlah sel Leydig. Data yang diperoleh dianalisis menggunakan ANOVA yang dilanjutkan dengan Uji Duncan dengan taraf kepercayaan 95\% dengan menggunakan perangkat lunak SPSS 16.0. Penelitian ini menunjukkan bahwa pemberian teh kombucha fermentasi 6, 9, dan 12 hari menurunkan diameter tubulus seminiferus sehingga berpotensi mengganggu proses spermatogenesis, tetapi tidak mempengaruhi jumlah sel Leydig tikus putih (Rattus norvegicus).
\end{abstract}

Kata kunci: Rattus norvegicus, teh kombucha , tubulus seminiferus, sel leydig

\section{ABSTRACT}

The objective of this study was to analyze the number of leydig cells and testicular microanatomy structure of Rattus norvegicus after treatment by $50 \%$ kombucha tea with variation of fermentation time. Sixteen male of rats, 2 months of age were used as experimental animals treated with kombucha tea that had been fermented for 6,9 and 12 days at the temperature of $25^{\circ} \mathrm{C}$ per oral. This research was using completely randomized design with 4 treatment (for 4 weeks) and 4 replications, namely: $\mathrm{P} 0=$ control, without of kombucha tea, $\mathrm{P} 1=$ water $+1,8 \mathrm{ml}$ kombucha tea that had been fermented for 6 days in the morning and afternoon, $\mathrm{P} 2=$ water $+1,8 \mathrm{ml}$ kombucha tea that had been fermented for 9 days in morning and afternoon, P3 = water $+1,8 \mathrm{ml}$ kombucha tea that had been fermented for 12 days in morning and afternoon. The variables measured were seminiferous tubule diameter and Leydig cell counts. Data were analyzed with ANOVA followed by Duncan test at $95 \%$ significance level were performed using SPSS version 16,0. The results showed that kombucha tea decreased the diameter of the seminiferous tubule, showing the potention of spermatogenesis disturbance, but did not affect Leydig cell counts of Rattus norvegicus.

Keywords: Rattus norvegicus, kombucha tea, seminiferous tubule, leydig cell

\section{PENDAHULUAN}

Minuman teh kombucha menyegarkan dengan rasa sedikit manis dan sedikit asam yang dikonsumsi secara mendunia. Teh kombucha diperoleh dari hasil fermentasi simbiosis bakteri dan ragi membentuk "jamur teh" (Chen and Liu, 2000). Lapisan selulotik tipis terapung dan cairan seduhan asam merupakan 2 bagian dari teh kombucha (Dufrense and Farnworth, 2000). Teh 
kombucha dipersiapkan dengan menaruh kultur kombucha (jamur teh) kedalam seduhan teh manis untuk fermentasi. Jika kultur kombucha dibudidayakan sesuai dengan resep standar menggunakan teh hitam, dipermanis dengan sukrosa, maka substansi ini akan berubah menjadi minuman teh jamur menyegarkan dengan nilai gizi tinggi dan kandungan berkhasiat medis (Loncar $e t$ al., 2000).

Chen and Liu (2000) menyatakan kandungan ethanol pada kombucha meningkat seiring waktu dan mencapai nilai tertinggi pada sekitar 5,5 g/L, diikuti dengan penurunan yang lambat. Kusumah dan Ismail (2010) menunjukkan pemberian teh kombucha dengan dosis bertingkat dapat menyebabkan perubahan gambaran struktur histologis hepar mencit Balb/c berupa degenerasi parenkimatosa, degenerasi hidropik, dan nekrosis sesuai dosisnya. Hasil penelitian Yuanita dan Ismail (2010) juga menunjukkan pemberian teh kombucha dosis bertingkat menyebabkan perubahan strukur histologis ginjal mencit Balb/c berupa penutupan lumen tubulus proksimal. Isdadiyanto dan Tana (2019) menyatakan bahwa pemberian teh kombucha kadar $75 \%$ menurunkan diameter tubulus seminiferus hingga berpotensi mengganggu proses spermatogenesis dan tidak mempengaruhi sel Leydig tikus putih.

Penelitian menunjukkan alkohol merupakan zat yang bersifat sitotoksik pada testis. Luka pada jaringan testis dapat berakibat pada menurunnya produksi sperma atau mengurangi sekresi testosteron dari testis dan gangguan transportasi sperma melalui sistem saluran atau pengiriman ke dalam saluran kelamin betina. Kualitas sperma yang tersedia untuk fertilisasi juga dapat terganggu (Creasy, 2001).. Menurut El-Sokkary (2001) pemberian alkohol secara kronik mampu menyebabkan penurunan diameter tubulus seminiferus, jumlah sel spermatogenik, dan kemunculan sel-sel germinal yang mati serta mengalami vakuolasi berbagai ukuran. Alkohol juga mampu menyebabkan penurunan jumlah dan volume inti sel Leydig secara signifikan. Keragaman fungsional dari sistem reproduksi jantan dan kompleksitas regulasi hormonnya memberikan lokasi potensial untuk gangguan kimiawi. Tujuan penelitian ini untuk mengkaji potensi teh kombucha kadar 50\% dengan variasi waktu fermentasi dalam mempengaruhi jumlah sel Leydig dan struktur mikroanatomi testis tikus putih (Rattus norvegicus).

\section{METODE PENELITIAN}

Penelitian dilakukan di Laboratorium Biologi Struktur dan Fungsi Hewan Departemen Biologi Fakultas Sains dan Matematika Universitas Diponegoro Semarang. Hewan percobaan menggunakan tikus putih (Rattus norvegicus) jantan sebanyak 16 ekor umur 2 bulan, sedang untuk bahan perlakuan yaitu teh kombucha kadar $50 \%$ yang difermentasi selama 6,9 dan 12 hari pada suhu $25^{\circ} \mathrm{C}$ per oral dengan spuit injeksi ujung berkanul. Adapun alat-alat yang digunakan yaitu 20 kandang individu yang dilengkapi dengan tempat minum dan pakan, gelas ukur, timbangan digital, disetting set.

Penelitian ini menggunakan Rancangan Acak Lengkap dengan 4 perlakuan dan 4 ulangan yaitu : $\mathrm{P} 0=$ kontrol, tanpa tambahan teh kombucha, $\mathrm{P} 1=$ air minum $+1,8 \mathrm{ml}$ teh kombucha kadar $50 \%$ pagi dan sore fermentasi 6 hari, $\mathrm{P} 2=$ air minum + $1,8 \mathrm{ml}$ teh kombucha kadar $50 \%$ pagi dan sore fermentasi 9 hari, $\mathrm{P} 3=$ air minum $+1,8 \mathrm{ml}$ teh kombucha kadar $50 \%$ pagi dan sore fermentasi 12 hari. Pakan dan minum diberikan secara ad libitum .Preparat histopatologi testis dibuat dengan metode parafin dan fiksatif yang digunakan adalah larutan $10 \%$ neutral buffered formalin. Tahapan yang dilakukan setelah proses fiksasi adalah melakukan pemotongan tipis jaringan setebal kurang lebih 4 $\mathrm{mm}$ dengan orientasi sesuai dengan organ yang akan dipotong (trimming). Pisau yang digunakan untuk trimming adalah pisau skalpel No. 22-24. Jumlah potongan jaringan yang dapat dimuat dalam embedding cassette berkisar antara 1-5 buah disesuaikan dengan ukuran organ. Dehidrasi jaringan dilakukan setelah trimming menggunakan tissue processor (Leica, Germany), ini dimaksudkan untuk mengeluarkan air yang terkandung dalam jaringan dengan menggunakan cairan dehidran seperti etanol atau iso propyl alkohol. Cairan dehidran kemudian dibersihkan dari dalam jaringan dengan menggunakan reagen pembersih (clearing agent) yaitu xylol. Reagen pembersih ini akan diganti dengan parafin dengan 
cara dimasukkan dalam larutan parafin cair sehingga parafin terpenetrasi ke dalam jaringan; proses ini disebut impregnasi. Parafin yang digunakan mempunyai titik cair $56-58^{\circ} \mathrm{C}$. Pengaturan waktu dehidrasi pada tissue processor diberikan pada pada Tabel 1. Setelah melalui proses dehidrasi, jaringan yang berada di dalam embedding cassette dipindahkan ke dalam base mold, kemudian diisi dengan parafin cair dan dilekatkan pada embedding cassette yang disebut blok. Jaringan dalam blok yang telah dingin, selanjutnya dipotong pada ketebalan irisan $4 \mu$ dengan rotary microtome. Irisan tersebut ditempel pada gelas objek yang sebelumnya diolesi Mayer's egg albumin dan ditetesi aquades kemudian dibiarkan kering pada suhu kamar. Selanjutnya setelah preparat mikroanotomi kering dilakukan pewarnaan dengan metode pewarnaan Hematoxylin Ehrlich-Eosin, kemudian dilakukan mounting dengan meneteskan entelan secukupnya dan ditutup dengan coverglass. Pengamatan preparat pada setiap perlakuan dilakukan dengan mikroskop cahaya untuk menentukan jumlah sel leydig dan diameter tubulus seminiferus antar kelompok perlakuan.

Tabel 1. Pengaturan waktu dehidrasi pada tissue processor

\begin{tabular}{lll}
\hline Proses & Cairan & Waktu \\
\hline Dehidrasi & Alkohol 80\% & 2 jam \\
& Alkohol 95\% & 2 jam \\
& Alkohol 95\% & 1 jam \\
& Alkohol absolut & 1 jam \\
& Alkohol absolut & 1 jam \\
Clearing & Alkohol absolut & 1 jam \\
& Xylol & 1 jam \\
Impregnasi & Xylol & 1 jam \\
& Xylol & 1 jam \\
& Parafin & 2 jam \\
& Parafin & 2 jam \\
\hline
\end{tabular}

Variabel yang diukur adalah jumlah sel Leydig dan diameter tubulus seminiferous. Data yang diperoleh dianalisis dengan ANOVA, berdasarkan Rancangan Acak Lengkap (RAL) pada taraf kepercayaan 95\% $(\alpha=0,05)$ (Mattjik dan Sumertajaya, 2006). Analisis keseluruhan menggunakan perangkat lunak software SPSS 10,0.

\section{HASIL DAN PEMBAHASAN}

Hasil penelitian tentang pengaruh pemberian teh kombucha dengan waktu fermentasi berbeda terhadap jumlah sel Leydig dan diameter tubulus seminiferus tikus pada taraf kepercayaan 95\% dapat dilihat di Tabel 2. Ratarata jumlah sel Leydig (Gambar 1) tidak menunjukkan beda nyata pada perlakuan $\mathrm{P} 0, \mathrm{P} 1$, $\mathrm{P} 2$, dan P3, demikian juga dengan kenampakan mikroanatominya. Hasil ini menunjukkan teh kombucha dengan fermentasi 6, 9, dan 12 hari konsentrasi $50 \%$ tidak menyebabkan perubahan pada struktur sel Leydig. Fungsi sel Leydig menurut Dong and Hardy (2004) adalah sumber utama dari hormon androgenik testosteron, yang penting untuk diferensiasi seksual jantan, produksi gamet dan pematangan, dan pengembangan karakteristik seksual sekunder. Menurut Creasy (2001) fungsi utama sel Leydig adalah steroidogenesis, sehingga zat apa pun yang mengganggu jalur metabolismenya akan menghasilkan gangguan fungsional dalam keseimbangan hormon. El-Sokarry (2011) menyatakan bahwa sel leydig rentan terhadap beberapa toksikan melalui efek langsung atau gangguan sumbu hipotalamus-hipofisis.

Menurut Dong and Hardy (2004), toksisitas dapat merusak sel Leydig dengan tiga cara: stimulasi berlebih atau penghambatan 
steroidogenesis, induksi pembentukan tumor, dan promosi kematian sel. Teh kombucha mengandung alkohol (Chen and Liu, 2000; Pratiwi dan Aryawati,2012) dan alkohol dapat menurunkan jumlah sel Leydig (El- Sokarry, 2011) serta menurunkan tingkat testosteron (Dong and Hardy, 2004). Peluang toksisitas alkohol pada teh kombucha berdasarkan hasil pengamatan tidak terlihat secara kuantitatif pada jumlah sel Leydig. Sel Leydig berkaitan dengan spermatogenesis karena menurut Holstein et al. (2003) sel Leydig mensekresikan testosteron dan zat neuroendokrin tambahan dan growth factor yang terlibat dalam pemeliharaan sel Sertoli dan sel jaringan peritubular; mempengaruhi kontraktilitas myofibroblasts dan mengatur pergerakan peristaltik tubulus seminiferus dan pengangkutan spermatozoa. Hasil pengukuran diameter tubulus seminiferus (Tabel 1) menunjukkan adanya perubahan berupa penurunan diameter tubulus seminiferus pada tikus yang diberi teh kombucha. Penurunan diameter menunjukkan adanya penurunan jumlah sel germinal (Lanning et al., 2002) yang bisa diasumsikan adanya gangguan pada siklus spermatogenik yang diregulasi oleh hormon androgenik dari sel Leydig.

Tabel 2. Hasil analisis rata-rata jumlah sel Leydig dan diameter tubulus seminiferus tikus.

\begin{tabular}{lcccc}
\hline & P0 & P1 & P2 & P3 \\
\hline $\begin{array}{l}\text { Jumlah Sel } \\
\text { Leydig (Sel) }\end{array}$ & $14,70^{\mathrm{a}} \pm 2,65$ & $12,35^{\mathrm{a}} \pm 0,96$ & $13,25^{\mathrm{a}} \pm 2,36$ & $13,75^{\mathrm{a}} \pm 2,36$ \\
$\begin{array}{l}\text { Diameter } \\
\text { tubulus }\end{array}$ & $291,856^{\mathrm{b}} \pm 4,37$ & $253,078^{\mathrm{a}} \pm 15,61$ & $252,212^{\mathrm{a}} \pm 10,38$ & $240,372^{\mathrm{a}} \pm 6,54$ \\
$\begin{array}{l}\text { seminiferus } \\
(\mu \mathrm{m})\end{array}$ & & & \\
\hline Keterangan: & $\begin{array}{l}\text { Angka yang ditunjukkan dengan superskrip yang sama pada baris yang sama menunjukkan perbedaan tidak } \\
\text { nyata (P>0,05). P0: Perlakuan Kontrol, P1: Pemberian teh kombucha fermentasi 6 hari, P2: Pemberian the } \\
\text { kombucha fermentasi 9 hari, P3: Pemberian teh kombucha fermentasi 12 hari. Data yang ditampilkan } \\
\text { berupa rerata } \pm \text { SD }\end{array}$
\end{tabular}

Nugroho (2009) menyatakan gangguan sintesis dan sekresi GnRH hipotalamus yang disebabkan oleh alkohol akan menyebabkan kegagalan hipofisis untuk melakukan sintesis dan sekresi FSH maupun LH. Gangguan hormon selanjutnya akan diikuti oleh kegagalan sel Leydig untuk mensintesis testosteron dan sel Sertoli tidak mampu melakukan fungsinya sebagai nurse cell. Alkohol menimbulkan gangguan pada hipotalamus dan hipofisis, selain itu juga bertindak sebagai inhibitor bagi enzim $5 \alpha$ reduktase. Enzim ini digunakan untuk mengubah prohormon (testosteron) menjadi bentuk aktifnya yaitu $5 \alpha$-dihidrotestosteron. Testosteron dalam bentuk aktif yang tidak dihasilkan akhirnya menyebabkan proses spermatogenesis tidak terjadi dan menyebabkan penurunan jumlah lapisan sel spermatogenik. Menurut Lanning et al. (2002) penurunan diameter tubulus seminiferus merupakan indikasi penurunan jumlah lapisan sel spermatogenik atau sel germinal.
Penelitian ini belum dapat dipastikan apakah teh kombucha yang tidak memberikan perubahan signifikan pada jumlah sel Leydig menunjukkan adanya penurunan hormon androgenik juga berpengaruh pada fertilitas. Untuk mengetahui pengaruh teh kombucha pada kesuburan secara langsung diperlukan penelitian lanjutan seperti jumlah spermatozoa dan kondisi hormonal hewan uji.Hasil analisis pengaruh pemberian teh kombucha berbeda hari fermentasi pada diameter tubulus seminiferus tikus dengan Analysis of Variance (ANOVA) menunjukkan hasil berbeda nyata $(\mathrm{P}<0,05)$ antara $\mathrm{P} 0$ (kontrol) dan P1 (fermentasi 6 hari) berupa penurunan diameter tubulus seminiferus testis, demikian juga dengan $\mathrm{P} 0$ dan $\mathrm{P} 2$ (fermentasi 9 hari), serta $\mathrm{P} 0$ dan P3 (fermentasi 12 hari). Hasil ini menunjukkan bahwa pemberian teh kombucha berpengaruh pada diameter tubulus seminiferus tikus.

Menurut Lanning et al. (2002), penurunan ukuran diameter tubulus seminiferus merupakan 
salah satu indikasi adanya kerusakan jaringan akibat dari penurunan jumlah sel germinal dan penurunan sekresi cairan tubular. Cairan tubulus seminiferus disekresikan oleh sel Sertoli dan berfungsi mempertahankan ukuran lumenal, yang bervariasi dengan tahap spermatogenesis. Sekresinya adalah bagian dari fungsi androgen yang bergantung pada sel Sertoli dan akan terpengaruh oleh sekresi testosteron yang berubah. Perubahan ini juga terlihat pada pengamatan mikroskopis. Hasil fotomikrograf (Gambar 1) menunjukkan adanya perbedaan berupa struktur tubulus seminiferus P0 memiliki susunan sel
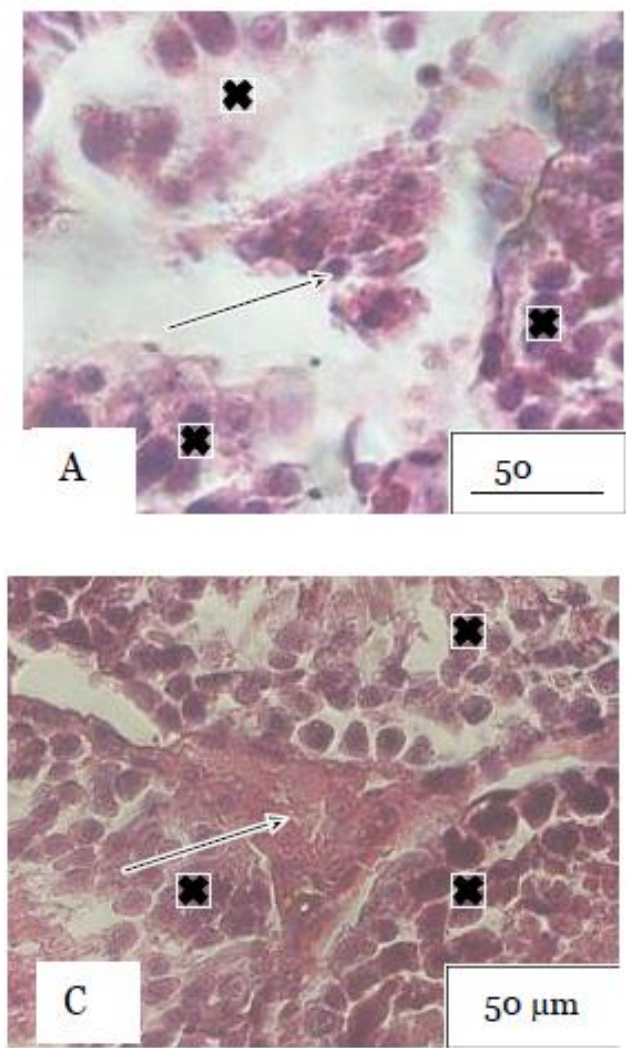

Gambar 1. Hasil Fotomikrograf Sel Leydig. Sel Leydig (ditunjukkan oleh panah) di antara tubulus seminiferus (ditunjukkan oleh tanda silang) pada perlakuan kontrol (A), pemberian teh kombucha fermentasi 6 hari (B), pemberian teh kombucha fermentasi 9 hari (C), dan pemberian teh kombucha fermentasi 12 hari (D) Perbesaran 400x dengan pewarnaan

Hasil pengukuran diameter tubulus seminiferus dan pengamatan mikroskopis menunjukan teh kombucha mempengaruhi struktur mikroanatomi testis tikus. Perubahan struktur mikroanatomi menunjukkan adanya zat berpotensi toksik yang terkandung dalam teh kombucha, dan salah satu yang sudah diketahui

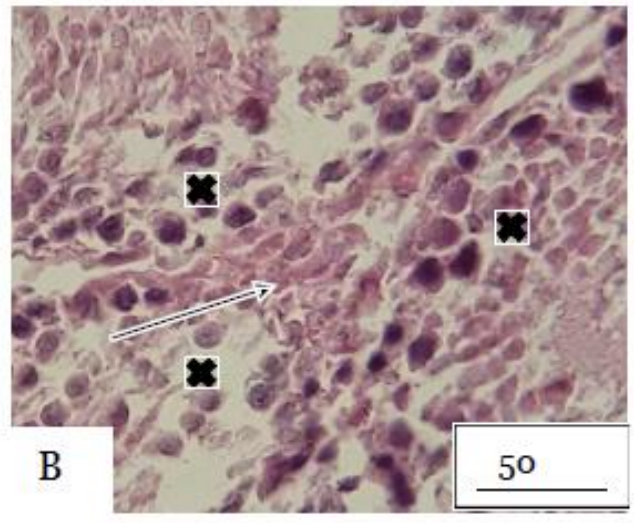

spermatogenik yang rapat dan kompak, sedangkan tikus dengan perlakuan P1, P2, dan P3 menunjukkan struktur sel spermatogenik yang semakin renggang seiring pertambahan waktu fermentasi dengan lumen yang tidak terisi penuh oleh spermatozoa. Menurut Waty et al. (2017), struktur mikroanatomi tubulus seminiferus yang normal akan menunjukkan asosiasi sel spermatogenik tersusun sesuai dengan tingkat perkembangannya dari membran basalis menuju ke arah lumen tubulus, yakni spermatogonia, spermatosit, dan spermatid.

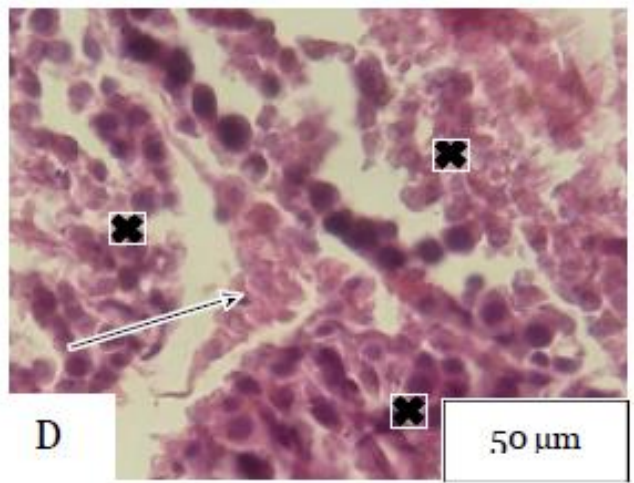

adalah alkohol atau ethanol. Chen and Liu (2000) menyatakan kandungan etanol pada teh kombucha mencapai nilai tertinggi pada sekitar $0,55 \%$ pada hari ke-20 diikuti dengan penurunan yang lambat, sedangkan menurut Pratiwi dan Aryawati (2012) mencapai $0,4683 \%$ pada hari ke 12 .

El-Sokarry (2011) menyatakan bahwa 
ukuran tubulus seminiferus bisa berkurang pada tikus yang mengkonsumsi alkohol. Rachadoul dan Sarkar (2013) menyatakan bahwa tingkat hormon testosteron menurun pada tikus dengan paparan alkohol yang diasosiasikan dengan penurunan FSH (Follicle Stimulating Hormone) dan LH (Luteinzing Hormone). Rachadoul dan Sarkar (2013) juga menyatakan bahwa asetaldehid, metabolit dari alkohol, bisa menghambat produksi testosteron dengan inhibisi protein Kinase $\mathrm{C}$ yang merupakan enzim kunci pada sintesis testosteron. Produksi sel germinal dan proses spermatogenesis pada testis sangat berkaitan dengan aktivitas hormonal. Holstein et al. (2003) menyatakan regulasi spermatogenesis membutuhkan rangsangan ekstratestikular dari hipotalamus dan hipofisis. Sekresi Gonadotropin-releasing Hormone $(\mathrm{GnRH})$ dari hipotalamus menginisiasi pelepasan Luteinzing Hormone (LH) dari hipofisis dan sebagai hasilnya menstimulasi sel Leydig untuk memproduksi testosteron. Testosteron tidak hanya mempengaruhi spermatogenesis pada tubulus seminiferus testis tetapi juga didistribusikan ke seluruh tubuh dan memberikan umpan balik terhadap hipofisis yang terkait dengan aktivitas sekretori sel Leydig.
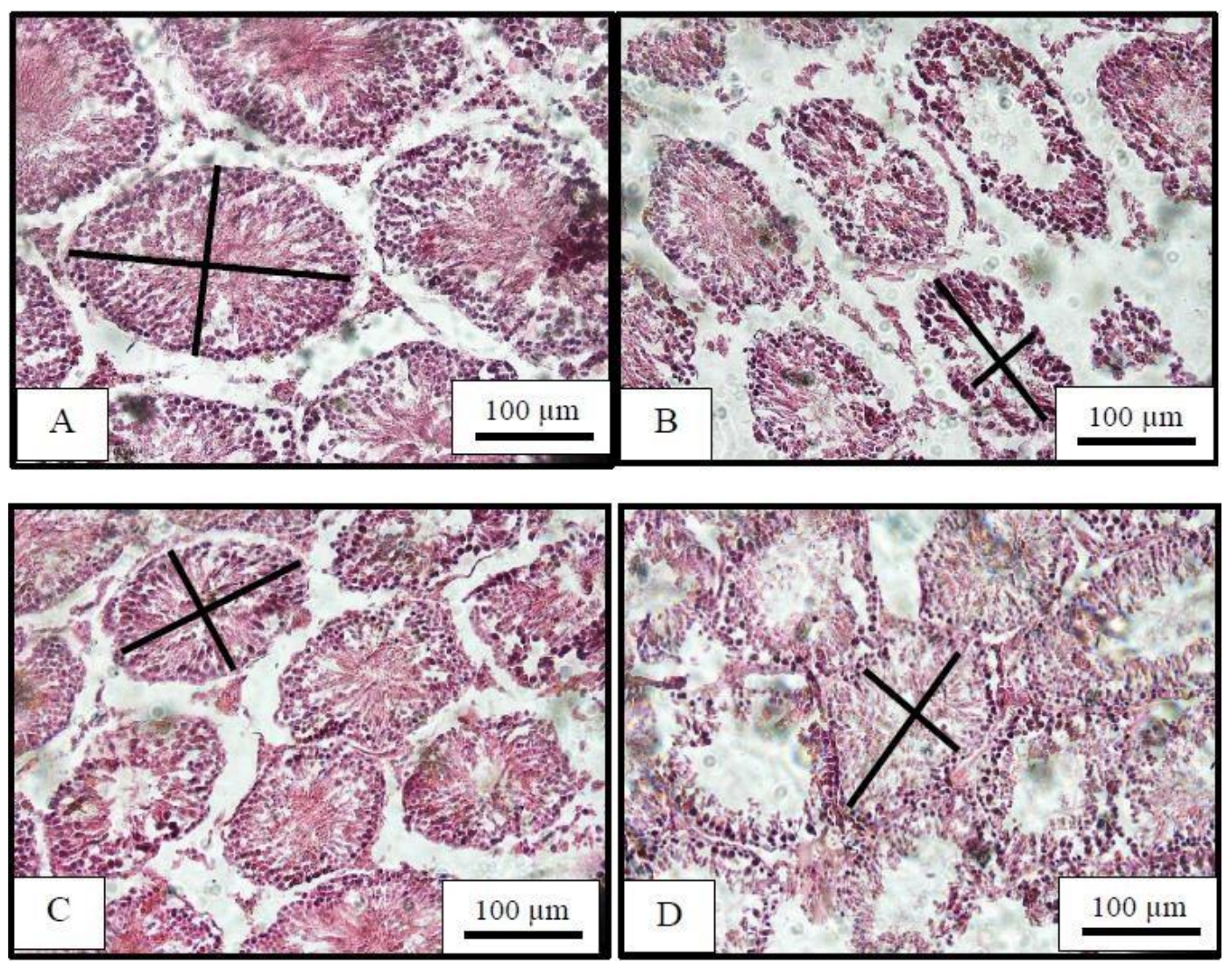

Gambar 2. Hasil fotomikrograf tubulus seminiferus Rattus norvegicus. Perlakuan kontrol (A), pemberian teh kombucha fermentasi 6 hari (B), pemberian teh kombucha fermentasi 9 hari (C), dan pemberian teh kombucha fermentasi 12 hari (D). Garis menunjukkan pengukuran diameter tubulus seminiferus. Pewarnaan H\&E perbesaran 100x.

Perubahan struktur tubulus seminiferus menghasilkan dugaan awal bahwa bahwa pemberian teh kombucha yang mengandung ethanol bisa memberikan pengaruh buruk pada tingkat fertilitas kelamin jantan, akan tetapi menurut Creasy (2001) apabila ada zat bersifat toksik yang merusak sel germinal, kematian sel yang benar-benar mempengaruhi kesuburan bergantung pada populasi sel germinal yang terkena dampak toksiknya. Semisal, apabila spermatogonia pada tikus mati, kesuburan tidak akan terpengaruh hingga 8-10 minggu semenjak paparan zat toksin. Maka dari itu, masih ada kemungkinan bahwa sel germinal pada tubulus 
seminiferus tikus yang diberi teh kombucha untuk kembali pulih. Kemungkinan pemulihan sel germinal ini menunjukkan perlu adanya penelitian kualitas dan kuantitas sperma dari tikus yang diberi teh kombucha.

\section{KESIMPULAN}

Penelitian ini menunjukkan bahwa pemberian teh kombucha fermentasi 6, 9, dan 12 hari menurunkan diameter tubulus seminiferus sehingga berpotensi mengganggu proses spermatogenesis, tetapi tidak mempengaruhi jumlah sel Leydig tikus putih (Rattus norvegicus).

\section{DAFTAR PUSTAKA}

Chen and Liu. (2000). Changes in major components of tea fungus metabolites during prolonged fermentation. Journal Applied Microbiology 89(5):834-839.

Creasy, D.M. (2001). Pathogenesis of Male Reproductive Toxicity. ToxicologicPathology, 29(1), 64 -76

Cunningham, J.G. and Klein, B.G. (2007) Textbook of Veternary Physiology. London: Saunders/Elsevier

Dong, Q. and Hardy, M.P. (2004). Leydig Cell Function in Man. In Winters, $\mathrm{S}$ \& Huthaniemi, I.T (Ed.). Male Hypogonadism: Basic, Clinical, and TherapeuticPrinciple. New Jersey: Humana Press Inc.

Dufrense and Farnworth. (2000). Tea, kombucha, and health: a review. Food Research International, 33(6), 409-21

El-Sokarry, G.H. (2001). Quantitative Study on The Effects of chronic Ethanol Administration on Testis of Adult Male Rat. Neuroendocrinology Letters, 22(2),93- 99

Hughes, I.A. and C.L. Acerini. 2008. Factors controlling testis descent. European Journal of Endocrinology, 159, 575-582.

Isdadiyanto, S. dan Tana, S. (2019). Struktur mikroanatomi testis tikus putih (rattus norvegicus) setelah pemberian teh kombucha konsentrasi $75 \%$ waktu fermentasi 6, 9 dan 12 hari. J. Bioma: Berkala ilmiah Biologi 21(1).

Jayabalan, R. Malbasa, R. Loncar, E. Vitas, J. and Sathiskumar, M. (2014). A Review on Kombucha Tea-Microbiology, Composition, Fermentation, Beneficial Effects, Toxicity, and Tea Fungus. Comprehensive Reviews in Food Science and Food Safety, 13(4), 538-55

Kusumah, L.P. dan Ismail A. (2010). Pengaruh Pemberian Teh Kombucha Per Oral Dengan Dosis Bertingkat Terhadap Gambaran Histologis Hepar Mencit Balb/C. 02 Desember 2010. Universitas Diponegoro Semarang, Fakultas Kedokteran http://eprints.undip.ac.id/24315/

Mattjik, A.A. dan Sumertajaya, I.M. 2006. Perancangan Percobaan dengan Aplikasi SAS dan Minitab. Ed. Ke-3. IPB-Press. Bogor.

Lanning, L.L. Creasy, D.M. Chappin, R.M. Mann, P.C. Barlow, N.J. Regan, K.S. and Goodman, D.G. (2002). Recommended Approaches for the Evaluation of Testicular and Epididymal Toxicity. Toxicologic Pathology, 30(4), 507520

Loncar, E.S. Petrovic, S.E. Malbasa, R.V. and Verac, R.M. (2000). Biosynthesis of glucuronic acid by means of tea fungus. Nahrung, 44(2),138-9.

Nugroho, C.A. (2009). Pengaruh Minuman Beralkohol Terhadap Jumlah Lapisan Sel Spermatogenik dan Berat Vesikula Seminalis Mencit. Widya Warta, 33(1), 4152

Pratiwi, A.E. dan Aryawati, R. (2012). Pengaruh Waktu Fermentasi terhadap sifat fisik dan kimia pada pembuatan minuman kombucha dari Rumput Laut Sargassum sp. Maspari Journal, 4(1), 131-136.

Rachadoul, N. and Sarkar, D.K. (2013). Effects of Alcohol on the Endocrine System.Endocrinology Metabolism Clinics of North America, 42(3), 593-615 
Waty, M. Tana, S., \& Saraswati, T. (2017). Histologis Testis pada Keturunan F1 dari Induk Puyuh (Coturnix coturnix japonica L.) yang diberi Suplemen Serbuk Kunyit (Curcuma longa L.) dalam Pakan. Bioma : Berkala Ilmiah Biologi, 19(1), 13-17. doi:http://dx.doi.org/10.14710/bioma, 19, $\underline{1,13-17}$

Yuanita, D.A dan Ismail, A. (2010). Pengaruh Pemberian Teh Kombucha Dosis Bertingkat Per Oral Terhadap Gambaran Histologi Ginjal Mencit Balb/C. 02 Desember 2010, Fakultas Kedokteran, Universitas Diponegoro Semarang. http://eprints.undip.ac.id/24332/ 